\title{
The Presence of Mercury Resistant Bacteria in Sediment of Gold Processing Plant at Waekerta Village of Buru District, Maluku Province and Their Activity in Reducing Mercury
}

\author{
SARMAWATY KOTALA ${ }^{1}$, RETNO KAWURI ${ }^{2}$ and IDA BAGUS WAYAN GUNAM ${ }^{3}$
}

\author{
${ }^{1}$ Student of Magister Biology Science Udayana University, Bali - 80114, Indonesia. \\ ${ }^{2}$ Biology Department, Faculty of Mathematic and Natural Sciences, \\ Udayana University, Bali - 80361, Indonesia. \\ ${ }^{3}$ Agroindustrial Technology Department, Udayana University, Bali - 80361, Indonesia.
}

http://dx.doi.org/10.12944/CWE.9.2.07

(Received: April 21, 2014; Accepted: May 17, 2014)

\begin{abstract}
Mercury was one of the heavy metal polute in environment and had the toxic characteristic to the living creatures. Golden mining in Waeapo subdistrict used mercury to extract the gold and exile the waste to the environment freely. Several precedented research showed that waste sediment of gold processing contains mercury resistance bacteria. Mercury resistance bacteria can be used as bioremediation agent because those bacteria can reduce mercury. Mercury resistance bacteria has mer operon which contained in plasmid. The goal of this research is to isolate mercury resistance bacteria which is able to grow on medium nutrient agar (NA) containing $500 \mathrm{ppm}$ of $\mathrm{HgCl}_{2}$ and to analyze the capability in $\mathrm{HgCl}_{2}$ reduction in nutrient broth (NB) medium. Bacteria isolation was done by platting method on Nutrient Agar containing $10 \mathrm{ppm}$ of $\mathrm{HgCl}_{2}$. Bacteria identification was done by kit Microgen TM GnA + B-ID System and to know bacteria capability in reducing mercury was done by CV-AAS (Cold Vapour Atomic Absorption Spectrophotometer). Result showed, that the bacteria found in this research were Bacillus sp and Aeromonas hydrophila. Both of these bacteria were able to reduce $\mathrm{HgCl}_{2}$ in the amount of $98,7 \%$ for Bacillus sp and $98,33 \%$ for Aeromonas hydrophila. In the future those bacteria can be use as bioremediation agent.
\end{abstract}

Key words: Mercury Resistant Bacteria, Bacillus sp, Aeromonas hydrophila, Gold Processing.

\section{INTRODUCTION}

Mercury utilizing in golden mining could produce waste, which contains mercury and causes environment pollution. Mercury belongs to heavy metal which is toxic to living creatures. Mercury can attack the arrangement of central nervous and causes memory loss, tremors and decreases motion capability. Poisoning causing destruction of a fetus has been detected. Miniamata desease in Japan is the example of mercury poisoning ${ }^{1,2}$.

Mercury as a pollutant in the environment need attention and problem solving. Mercury detoxification can be done chemically by precipitation, coagulation, reverseosmosis, ion exchange resins and adsorption using activated carbon ${ }^{3,4}$. However, this process is relatively expensive and could cause new problems, namely the accumulation of these compounds insediment and aquatic organisms ${ }^{4}$.

Mercury detoxification can be done by using mercury resistance bacteria which have mercury resistance gen, called mer operon ${ }^{4,5}$. There is gold mining at Waekerta village, Sub district Waeapo, Maluku Province, Indonesia, where the processing of gold using mercury and the waste is discharged into the environment without regard to the contamination occurred (Figure 1). Based on this background, it is necessary to isolate mercury resistance bacteria 
from sediment of gold processing which able to grow on NA medium containing $500 \mathrm{ppm}$ of $\mathrm{HgCl}_{2}$ and to analize the capability of reduction of $\mathrm{HgCl}_{2}$.

\section{MATERIAL AND METHODS}

\section{Research Materials}

This study used a sample of sediment taken from a waste disposal site of gold processing in Waekerta Village, Maluku. Materials used in this study were Nutrient Agar (Merck),Nutrient Broth (Merck), and $\mathrm{HgCl}_{2}$.

\section{Research Instrument}

The instrument used in this research is a hot plate, autoclave, vortex, incubator, kit Microgen TM GnA + B-ID System, microscopes, spectrophotometers, CV-AAS, and laminar air flow cabinet.

\section{Sampling}

Samples were taken as much as $20 \%$ from 42 gold processing sites in Waekerta Village, so that 9 locations were choose to get the sediment samples. Samples taken from each location on 5 different points were then mixed into one. Land sample from mining land was used as comparative so that total of all samples become ten. Location of sampling sites in the village of Waekerta as shown in Figure 2.

\section{Bacteria Isolation}

Mercury resistance bacteria isolation was done by spread plate method ${ }^{6}$. Sedimen and soil sample were diluted in a series $\left(10^{-1}, 10^{-2}\right.$ and $\left.10^{-3}\right)$ with saline solution $(0.85 \% \mathrm{NaCl})$. From the $10^{-3}$ dilution were taken $0,1 \mathrm{ml}$ and spread on petri dishes containing selective media namely nutrient agar (NA) containing $10 \mathrm{ppm}$ of $\mathrm{HgCl}_{2}$. Then incubated at room temperature for 3 days. Grown bacterial isolates with different colonies morphological characters were reisolated again to a new medium in order to get pure cultures and stored in an agar slant for further testing.

\section{Mercury Recistance Bacteria Selections}

Bacteria selection is based on the ability of bacterial isolates grown in medium with various $\mathrm{HgCl}_{2}$ concentrations. Bacterial isolates were grown by streaking method on NA medium which contain $25 \mathrm{ppm}$ of $\mathrm{HgCl}_{2}$ and incubated at room temperature for 24 hours. If the isolates grow, then chese bacterial isolates were re-grown by streaking method on the NA medium added with $\mathrm{HgCl}_{2}$ with a higher concentration of 50 ppm, 100 ppm, 250 ppm, 400 ppm, 500 pp min order to obtains uperior isolates, which were able to live in the highest $\mathrm{HgCl}_{2}$ concentration. Purified isolates was stored in nutrient agar slant medium with a temperature of $20^{\circ} \mathrm{C}$.

\section{Mercury Resistance Bacteria Identification}

Parameters observed for identification of mercury-resistant bacteria are colony form on NA medium, Gram staining, and character physiology (biochemical test). Physiological characteristics were tested using Microgen ${ }^{\mathrm{TM}}$ kit GNA+B-ID System Identification (Microgen Bioproduct, UK).

\section{Determination of Optimum Temperature on the Growth of Mercury Resistant Bacteria}

To determine the optimum growth temperature, the bacterial isolates were grown on nutrient broth medium and incubated a variety of temperature is: $25^{\circ} \mathrm{C}, 30^{\circ} \mathrm{C}, 37^{\circ} \mathrm{C}$, and $45^{\circ} \mathrm{C}$. Cultures were incubated at this temperature for 24 hours. Further growth of the isolates was measured degree of turbidity with a spectrophotometer at a wavelength of $620 \mathrm{~nm}$. Absorbance values of bacterial cells can be observed at a wavelength of $620 \mathrm{~nm}$, each treatment was repeated 3 times.

\section{Determination of Optimum pH on Mercury Resistant Bacteria Growth}

To determine the optimum $\mathrm{pH}$ of growth, the bacterial isolates were grown in nurient broth with a $\mathrm{pH}$ of $5,6,7,8$, and 9. Cultures were incubated at the optimum temperature for 24 hours. Growth of isolates was measured with a spectrophotometer at a wavelength of $620 \mathrm{~nm}$ and each treatment was repeated 3 times.

\section{Determination of Bacterial Growth Curve}

Aseptically one ose of superior bacterial isolates at the age of 24 hours (isolates were rejuvenated on NA medium containing $10 \mathrm{ppm}$ of $\mathrm{HgCl}_{2}$ ) was inoculated in $100 \mathrm{ml}$ of NB medium in erlenmeyer flask, incubated at room temperature on a rotary shaker (100 rpm). 24-hour-old culture was washed using saline solution, then $5 \mathrm{ml}$ of the culture was taken and inoculated into $45 \mathrm{ml}$ of NB 
medium at a concentration of $10 \mathrm{ppm} \mathrm{HgCl}_{2}$ and incubated at room temperature on arotaryshaker (100 rpm). Suspension culture absorbance values were measured at a wavelength of $620 \mathrm{~nm}$. Absorbance measurements were started from 0 hour up to 72 hours with an interval of 4 hours. Obtained absorbance data was then conversed into the growth curve. On the $x$-axis is time and and on the $y$-axis is absorbance. The growth curve will be compared with the growth curve of bacteria in NB medium without $\mathrm{HgCl}_{2}$.

\section{Mercury Reducing Bacteria Activity Test}

Mercury reducing bacteria activity test was carried outtolook at the ability of superior isolates in reducing $\mathrm{Hg}$. In this testing phase bacterial isolates were grown in NB medium for 24 hours in $250 \mathrm{ml}$ erlenmeyer, then isolated cells were washed using saline solution and the absorbance was measured using a spectrophotometer at a wavelength of 620 $\mathrm{nm}$. Culture with absorbance value of 2 was taken $0.1 \mathrm{ml}$ and grown in $50 \mathrm{ml} \mathrm{NB}$ medium containing a concentration of $100 \mathrm{ppm} \mathrm{HgCl}_{2}$, then incubated for 7 days on top shaker (100 rpm). Furthermore, bacterial cells were separated from the medium by using a membran filter with the size of $0.2 \mu \mathrm{m}$. $\mathrm{Hg}$ concentration remaining in the medium was measured by Cold Vapour NB Atomic Absorption Spectrophotometer (CV - AAS). In addition, NB medium containing 100 ppm of $\mathrm{HgCl}_{2}$ without inoculated with bacteria resistant to mercury was used as a positive control and NB medium without $\mathrm{HgCl}_{2}$ and mercury resistant bacteria was used as negative control. The principle of CV-AAS working is to change the mercury dioxide compounds into the mercury ion, mercury ion subsequently reduced to metallic mercury and the cold vapor atomic absorption of it was analyzed at a wavelength of $253.7 \mathrm{~nm}$. Reagents used were $\mathrm{SnCl}_{2}$ reductant, $\mathrm{H}_{2} \mathrm{SO}_{4}+\mathrm{HCl}$ acid solution (Rondonuwu, 2011).To determine the levels of mercury removal efficiency, this formula was used:

$$
\mathrm{Eff}=(\mathrm{C} 1-\mathrm{C} 2) / \mathrm{C} 1 \times 100 \%
$$

Whereas: $\mathrm{C} 1$ = First concentration $(p p m) ; C 2=$ Final concentration $(p p m)$; Eff $=$ Efficiency

\section{Data Analysis}

The data were analyzed qualitatively and quantitatively. Qualitatively is by describing the results of the characterization and identification of mercury-resistant bacterial isolates were able to reduce mercury. Quantitatively, on the $\mathrm{pH}$ test and growth curve measurement was done by measuring the number of bacterial cells through the absorbance. The data obtained was made in the form of a bar graph, but the growth curve in the form of a line graph using Microsoft Excel program.

Table 1: Characteristic of L.10b and L.10c

\begin{tabular}{|c|c|c|}
\hline Characteristic & L.10b & L. $10 c$ \\
\hline Colony shape & Spherical & Irreguler \\
\hline Colony colour & Brown & Beige \\
\hline Edge & Smooth, flat & Irreguler \\
\hline Motility & Motil & Motil \\
\hline Shape of cell & Rod & Rod \\
\hline Gram staining & + & - \\
\hline Oxidase & + & + \\
\hline Nitrate & + & + \\
\hline Lysin & - & + \\
\hline Ornithine & - & - \\
\hline $\mathrm{H} 2 \mathrm{~S}$ & - & - \\
\hline Glucose & - & - \\
\hline Mannitol & - & - \\
\hline Xylose & - & - \\
\hline ONPG & + & + \\
\hline Indole & - & - \\
\hline Urease & - & + \\
\hline V.P. & - & - \\
\hline Citrate & - & - \\
\hline TDA & - & - \\
\hline Gelatine & - & - \\
\hline Malonate & - & - \\
\hline Inositol & - & - \\
\hline Sorbitol & - & - \\
\hline Rhamnose & - & + \\
\hline Sucrose & - & + \\
\hline Lactose & - & - \\
\hline Arabinose & + & + \\
\hline Adonitol & - & + \\
\hline Raffinose & - & - \\
\hline Salicin & - & + \\
\hline Arginine & - & + \\
\hline Species & Bacillus sp & $\begin{array}{c}\text { Aeromonas } \\
\text { hydrophila }\end{array}$ \\
\hline
\end{tabular}




\section{RESULTS AND DISCUSSION}

Two isolates of mercury resistant bacteria capable of living NA medium containing 500 ppm of $\mathrm{HgCl}_{2}$ was found in gold processing sediment samples. The isolates were L.10b and L.10c. After identification, these isolates were identified as Bacillus sp and Aeromonas hydrophyla. Both macroscopic and microscopic forms of the isolate scan be seen in Figure 3 and Figure 4 as well as the character of each isolate are shown in Table1.

Bacillus $\mathrm{sp}$ was found as a mercury resistant bacteria in Japan and India ${ }^{7}$. In addition, Bacillus sp was also found in the Tondano river, Indonesia ${ }^{8}$. Bacillus cereus and Bacillus subtilis found in the Kalimas river Surabaya are also resistant to mercury ${ }^{9}$. Bacillus $\mathrm{sp}$ is more often found as mercury resistant bacteria compared to Aeromonas hydrophila. Aeromonas hydrophyla has been found in gold mining sediment contaminated by Hgin Bandung, West Javaandable to grow at $550 \mathrm{mg} / \mathrm{L} \mathrm{HgCl}_{2}{ }^{10}$. In addition, some strains of A.hydrophila is found in sea water, fish, and waste water contaminated by heavy metals in Tunisia ${ }^{11}$.

Temperature is one of the environmental factors that influence the growth of bacteria. Bacillus $\mathrm{sp}$. has the highest absorbance value $(0.216)$ at $25^{\circ} \mathrm{C}$ and the lowest $(0.118)$ at a temperature of $45^{\circ} \mathrm{C}$. Aeromonas hydrophila has a high absorbance value $(0.404)$ at $37^{\circ} \mathrm{C}$ and the lowest $(0.224)$ at a temperature of $45^{\circ} \mathrm{C}$ (Figure 5). Temperature effect on bacterial growth because temperature affects the activity of enzymes in metabolism. The temperature affect the chemical reactions in the

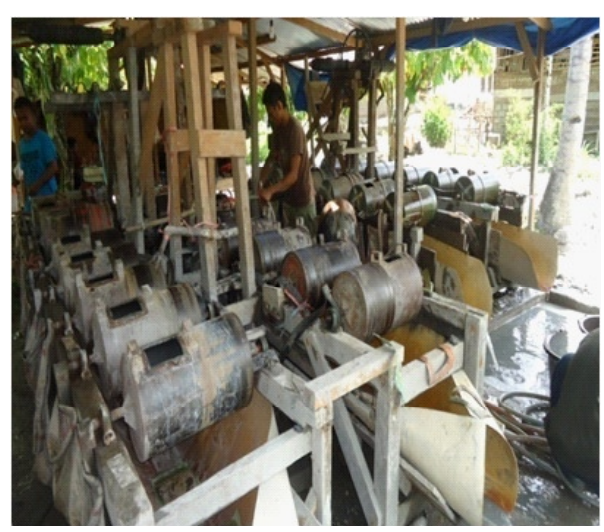

(a)

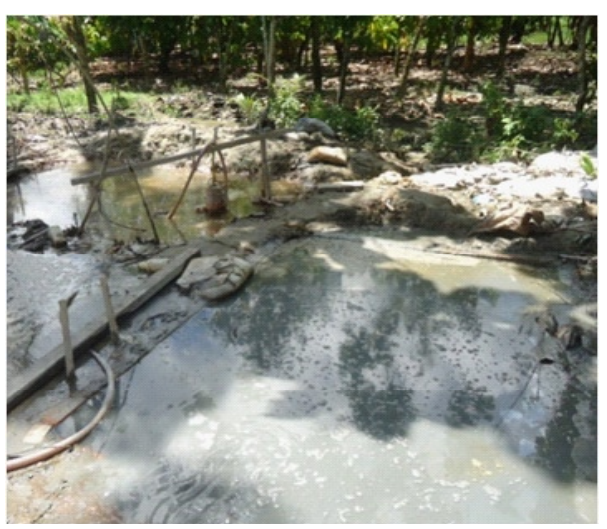

(b)

Fig. 1: Gold mining in Waekerta village(a) Gold processing, (b) Waste of gold processing in Environment

Table 2: The Test Results in Reducing Mercury

\begin{tabular}{lccc}
\hline Sample & $\begin{array}{c}\text { The concentration } \\
\text { of mercury } \\
\text { remaining in the } \\
\text { medium (ppm) }\end{array}$ & $\begin{array}{c}\text { Average } \\
\text { efficiency } \\
(\%)\end{array}$ & $\begin{array}{c}\text { Standard } \\
\text { deviation }\end{array}$ \\
\hline A & 1,67 & 98,33 & 0,172 \\
B & 1,33 & 98,7 & 0,162 \\
P & 100 & 0 & 0 \\
N & 0 & 0 & 0 \\
\hline
\end{tabular}

Description: $\mathrm{A}=$ treatment using bacteria Aeromonas hydrophila, $\mathrm{B}=$ treatment using bacteria Bacillus sp., $\mathrm{P}=$ positive control (NB medium containing $100 \mathrm{ppm}$ of $\mathrm{HgCl}_{2}$ ), $\mathrm{N}=$ negative control (NB medium without $\mathrm{HgCl}_{2}$ ). 
process of bacterial growth, growth rate, and the total amount of the growth of microorganisms ${ }^{12}$. Although the absorbance values of different bacteria are categorized both mesophilic bacteria. Mesophilic bacteria is a group of bacteria that can grow at a temperature of $20-45^{\circ} \mathrm{C}^{13}$.

Bacterial growth can be affected by various environmental factors, one of which is the $\mathrm{pH}$ of the medium. The degree of acidity of the medium affects the growth of Bacillus sp and A. hydrophyla. Bacillus $\mathrm{sp}$ grows optimally at $\mathrm{pH} 6$ with a absorbance value of 0.106 and the absorbance values decreased when the $\mathrm{pH}$ of the medium increased (Figure 6).
In contrast to Bacillus sp, $A$. hydrophila has the highest absorbance value $(0.192)$ at $\mathrm{pH} 7$ and the lowest (0.11) at $\mathrm{pH} 5$ (Figure 6). The degree of acidity affects the growth of bacteria because the $\mathrm{pH}$ affects the enzymes in the metabolism of bacteria. Enzyme activity will decrease if the $\mathrm{pH}$ is not appropriate, this is because the enzyme will be active in a proper state of ionization. The appropriate ionization conditions for different enzymes are also differ but generally ranges at $\mathrm{pH} 6-8^{14}$. The enzyme can be denatured due to changes in $\mathrm{pH}$. The enzyme works at neutral $\mathrm{pH}$ and will become inactive when the environment becomes very acidic or very alkaline ${ }^{15}$. Based on the growth ability in that $\mathrm{pH}$ range, Bacillus $\mathrm{sp}$, and

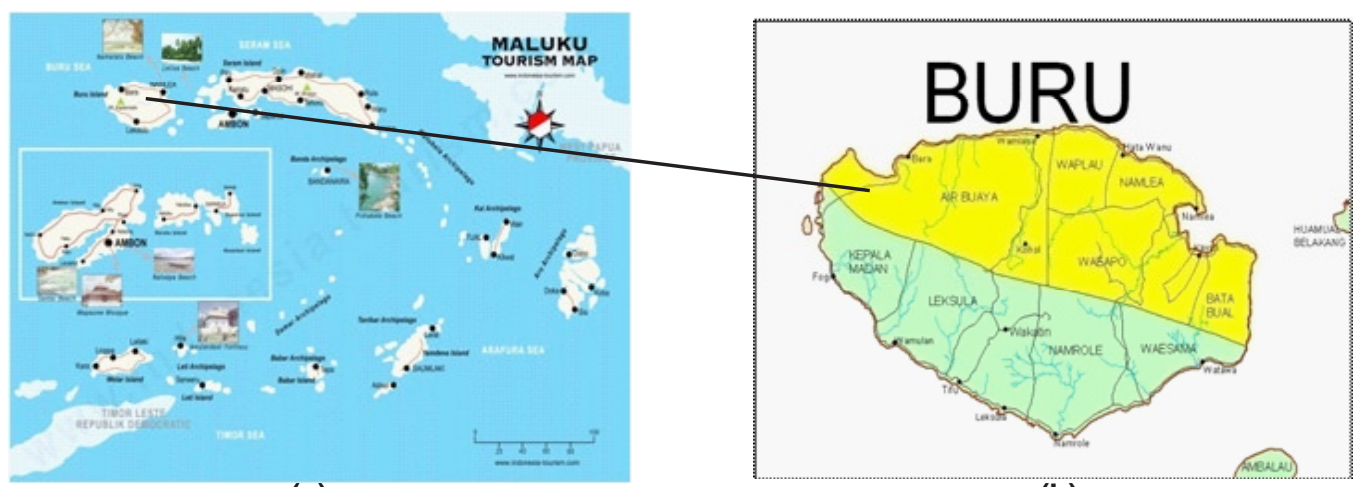

(a)

(b)

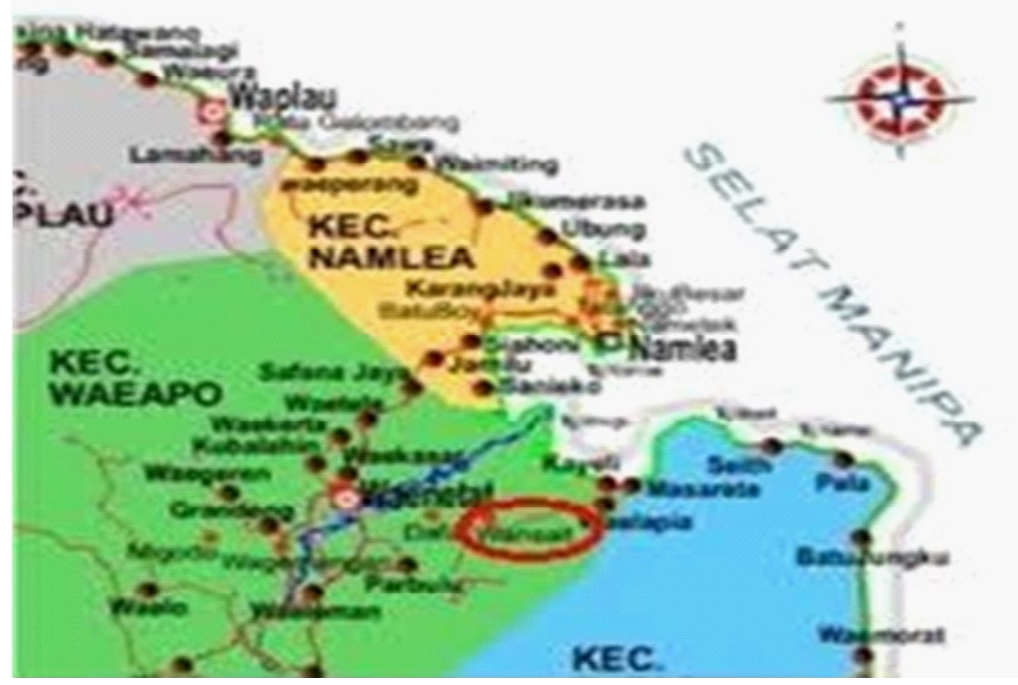

(c)

Fig: 2: Map of Sampling Location: (a) Map of Maluku Province, Indonesia (source: Malukuonline. co.id); (b) Map of Buru District (source: informasi-maluku.Blogspot.com); (c) Map of Waeapo Subdistrict, Waekerta Village (arrow) (source: minerthink.wordpress.com) 
A. hydrophila can be classified into the neutrophils bacteria. Neutrophil is a bacterial groups were able to grow at $\mathrm{pH} 6-8^{14,15}$.

The growth of Bacillus sp and Aeromonas hydrophila in NB medium containing $10 \mathrm{ppm}$ of $\mathrm{HgCl}_{2}$ and incubated for 3 days has not reached the stationary phase. The results obtained were different with control Bacillus sp, which reached stationary phase at 37 th and $A$. hydrophila which reached the stationary phase at the 44th and death phase in the 68th hour (Figure 7). During the period of incubation with medium containing $10 \mathrm{ppm} \mathrm{HgCl}_{2}$, both of these bacteria were only able to reach the exponential phase. Bacillus sp achieve exponential phase at 68th and $A$. hydrophila at 48th hours (Figure 7 ). This is because the adaptation phase is long enough. This is due to $\mathrm{HgCl}_{2}$ in the medium. In the adaptation phase the synthesis of the new enzymes occurs, according to the media and the increase of cell numbers not found ${ }^{14}$. The length of the adaptation phase in medium containing $\mathrm{HgCl}_{2}$ occur in bacteria Ochrobactrum sp S79 and L6T2 isolates, wherein the second stationary phase of these bacteria occurs on day 4 to day 9 of incubation time ${ }^{16}$.

Aeromonas hydrophila and Bacillus $\mathrm{sp}$ resistant and able to reduce mercury levels of 100 ppm to $1.67 \mathrm{ppm}$ for A.hydrophila and $1.33 \mathrm{ppm}$ for Bacillus sp after incubated for 7 days. The results of mercury content remaining in the medium, were used to determine the efficiency of both bacteria in reducing mercury. Bacillus sp able to reduce mercury by $98.7 \%$, where as A.hydrophila was $98.33 \%$ (Table 2). The ability of Bacillus sp and A.hydrophila in reducing mercury levels associated with a character

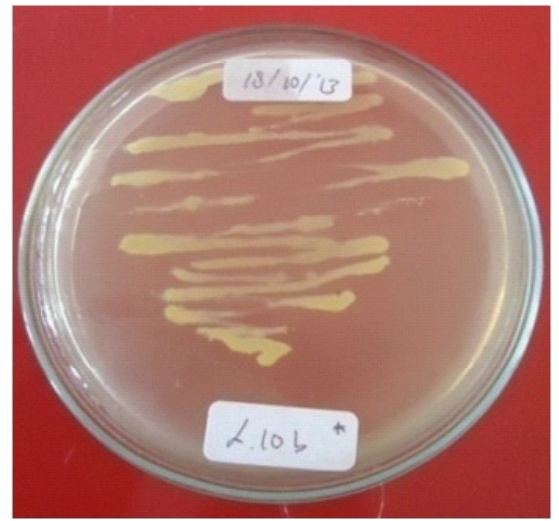

(a)

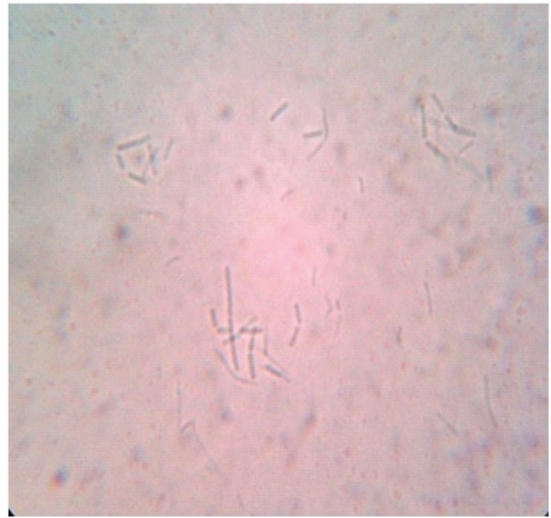

(b)

Fig. 3: (a) Bacillus sp, (b) microscopic, rod shape, 1000 x magnification (arrow)

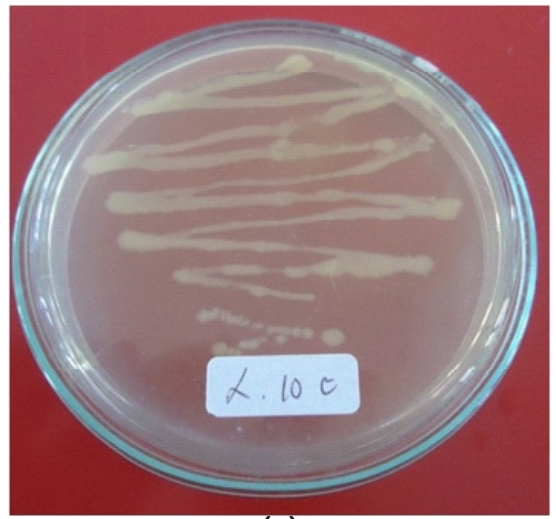

(a)

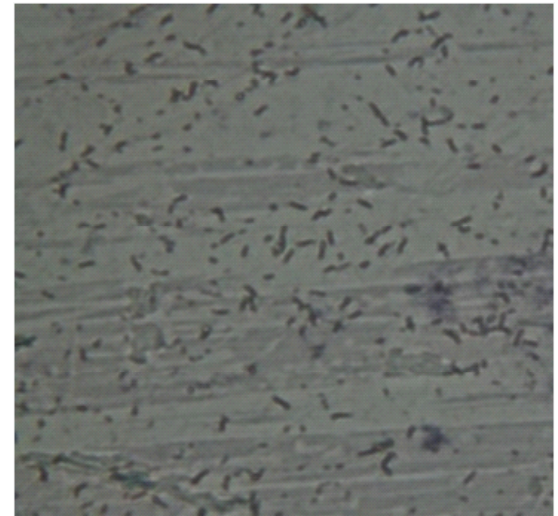

(b)

Fig. 4: (a) Aeromonas hydrophila, (b) microscopic, rod shape, 1000 x magnification 
that is resistant to mercury. Bacterial resistance to mercury due to the mer operon contained in the plasmid $^{4,5}$.

Mer operon consists of a wide variety of mergenes. Each bacterium has its own mergene variations in the mer operon ${ }^{3}$. But the mechanism of bacterial resistance to inorganic mercury is almost the same in different bacteria species. This is due to the reduction of mercury from $\mathrm{Hg}^{2+}$ to $\mathrm{Hg}^{0}$ induced by mercuric ion reductase enzyme encoded by the mer operongenes Mer $A^{2}$. Mercuric ion reductase formsa

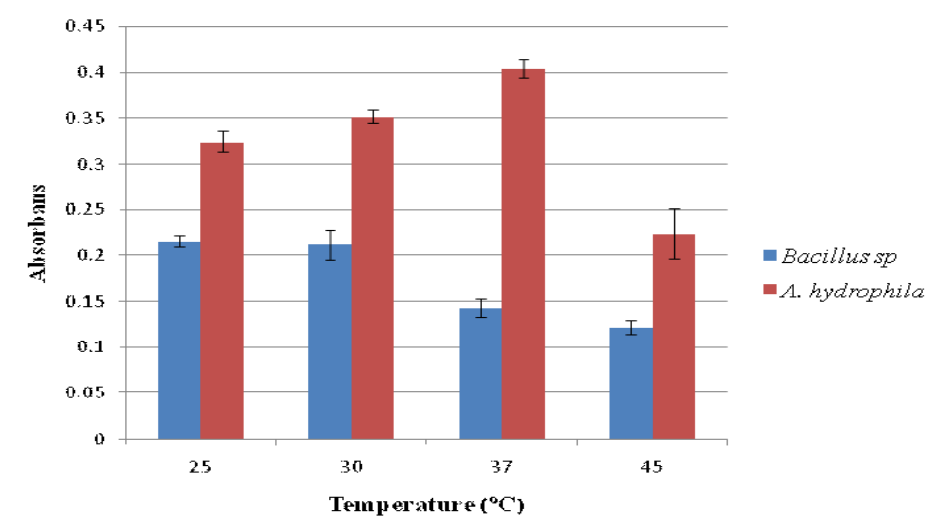

Fig. 5: Graph the effect of incubation temperature on the growth of mercury-resistant bacteria (incubation period of 24 hours)

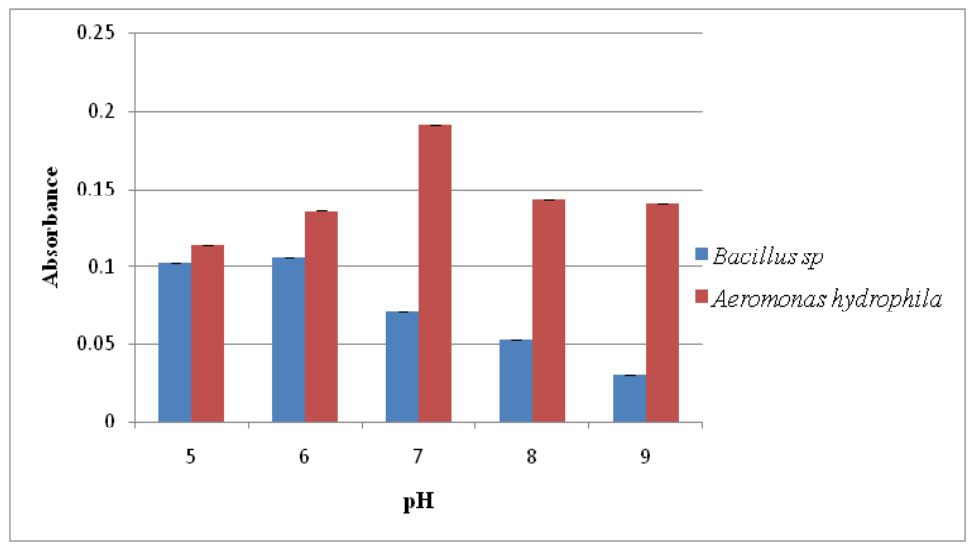

Fig. 6: Graph of the effect of $\mathrm{pH}$ on the growth of mercury-resistant bacteria

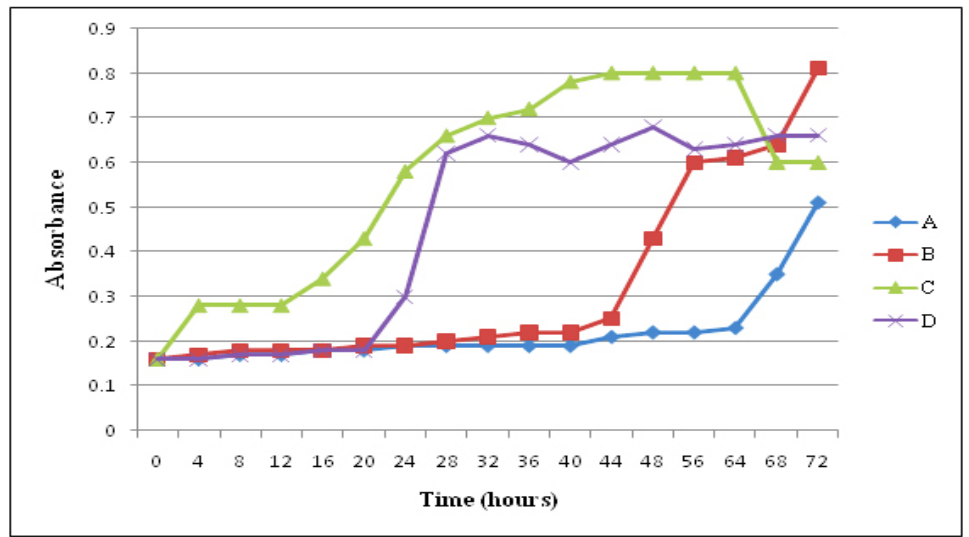

Fig. 7: The growth curve of bacteriain the medium $\mathrm{NB}$ containing $\mathrm{HgCl}_{2} 10 \mathrm{ppm}$ 
bond with $\mathrm{Hg}^{2+}$ and reduction occurs by the transfer of electrons through the flavin bond from NADPH into NADP, so that reduced $\mathrm{Hg}$ was formed, ie $\mathrm{Hg}^{05}$. The reduction of $\mathrm{Hg}^{2+}$ to $\mathrm{Hg}^{0}$ is away to remove oxidized mercury and to reduce mercury dissolved in a medium ${ }^{17}$.

Some bacteria of the Genus Bacillus are known to have a gene variation in meroperon. Bacillus megaterium and Bacillus macroides is abroad-spectrum mercury-resistant bacteria, whereas Bacillus cereus and Bacillus licheniformis are an arrow-spectrum mercury-resistant bacteria ${ }^{18}$. Bacteria which only has mercury reductase protein (MerA) is called by a narrow spectrum mercuryresistant bacteria, while broad-spectrum mercuryresistant bacteria are bacteria that have mercury reductase protein (MerA) and protein organo merkurilyase (MerB). Mer Bfunctions in catalyzing the termination of the mercury-carbon bond to produce organic compounds and ionic $\mathrm{Hg}$ in the form of salt thiols ${ }^{20}$. Bacillus sp and A.hydrophila found in this study are not known the extent of the spectrum which is owned in reducing mercury.

Until now there has been no reports of mergene variations that are owned by Aeromonas hydrophila. However other species of the Genus Aeromonas are known variations in the mer operongenes. Aeromonas salmonicida has some mergenes in the mer operon, namely Mer A,Mer $\mathrm{P}$, MerR, MerE, MerT, MerD, and MerB ${ }^{19}$. Aeromonas hydrophila is able to change the shape of the cells, from rod into a round shape after mercury exposure ${ }^{11}$.

\section{ACKNOWLEDGMENT}

The authors would like to express their aprreciation to the Head of Magister Biology Science and Udayana University Bali Indonesia for supporting this study. Appreciation is also send to Governor of Maluku province, Indonesia for the support in carrying out this research work.

\section{REFERENCE}

1. Chowdury, S., Bala, N.N., Dhauria, P. International Journal of Pharmaceutical, Chemical, and Biological Science 2(4): 600611 (2012).

2. UNEP. Global Mercury Assesment. InterOrganization Programme for The Sound Management of Chemicals.Issued by UNEP Chemicals. Geneva, Switzerland. (2002)

3. Okoronkwo, N. E., Igwe, J. C., Okoronkwo, I. J.African Journal of Biotechnology 6(4): 337 (2006)

4. Dash, H.R., Das, S. International Biodeterioration and Biodegradation. 75 : 207-213 (2012).

5. Barkay, T., Susan, M. M., Anne, O. S. FEMS Microbiology Reviews. 27: 355-384 (2003).

6. Dubey, R.C., D.K. Maheshwari. Practical Microbiology. S.Chand and Company LTD, New Delhi, 37 (2007)

7. Osborn, A.M., Kenneth, D.B., Peter, S., Donald, A.R. FEMS Microbiology Reviews. 19: 239-262 (1997)

8. Manampiring, A.E., Billy, J.K. Jurnal IImiah
Sains. 11 (1): 26-30 (2011)

9. Zulaika, E., Langkah, S., Agus, S. Journal of Basic and Applied Scientific Research, 2(7): 7263-7269 (2012)

10. Chaerun, S.K., Sakinah, H., Edy, S., Maelita, R.M. Microbiology, 6(2): 57-68 (2012)

11. Saidi, N., Rihab, L., Fethi, B.A., Karima, B.R., Amina, B. African Journal of Microbiology Research 7(50): 5697-5708 (2013)

12. Pelczar, M.J., Chan, E.C.S. Basic of Microbiology. Universitas Indonesia Publisher, Jakarta :138-139 (2010)

13. Perry, J.J., James, T.S., Stephen, L. 2002. Microbial Life. Sinauer Associates Publishers,Massachusetts: 142: (2002)

14. Purwoko, T. 2009. Physiology of Microbe. Penerbit Bumi Aksara, Jakarta, 234 (2009)

15. McKane, L., Judy, K. 1996. Microbiology Essentials and Aplications Second Edition. McGraw-Hill, USA, (1996)

16. Imamuddin, H. Jurnal Ekosains 2(1); 26-32 (2010).

17. Chowdury, S., Bala, N.N., Dhauria, P. 2012. 
International Journal of Pharmaceutical, Chemical, and Biological Science. 2(4), 600611 (2011).

18. Narita, M., Kazuyuki, C., Hiroshi, N., Hidenori, I., Chieh-Chen, H., Zen'ichiro, K., Simon, S., Ginro, E. FEMS Microbiology Reviews. 223; 73-82 (2003)

19. McIntosh, D., Michelle, C., Baijing, J., Frank,
A.F., Erin, M.P., Sarah, E.C., Zachary, B.Z., Ilana, C.G., Russel, D., Keith, A.J., Mike, B., Rachael, R. Journal of Antimicrobial Chemotheraphy. 61; 1221-1228 (2008)

20. Huang, C.C., Chien, M.F., Lin, K.H. Interdisciplinary Studies on Environmental Chemistry - Biological Responses to ContaminantsEds., 23-29 (2010). 